\title{
Effects of Contaminated St. Lucie River Saltwater Sediments on an Amphipod (Ampelisca abdita) and a Hard-Shell Clam (Mercenaria mercenaria)
}

\author{
Tham C. Hoang \\ Loyola University Chicago, thoang@luc.edu
}

Gary M. Rand

Florida International University

Follow this and additional works at: https://ecommons.luc.edu/ies_facpubs

Part of the Environmental Sciences Commons, and the Pharmacology, Toxicology and Environmental Health Commons

Author Manuscript

This is a pre-publication author manuscript of the final, published article.

\section{Recommended Citation}

Hoang, Tham C. and Rand, Gary M.. Effects of Contaminated St. Lucie River Saltwater Sediments on an Amphipod (Ampelisca abdita) and a Hard-Shell Clam (Mercenaria mercenaria). Archives of Environmental Contamination and Toxicology, 67, 2: 224-233, 2014. Retrieved from Loyola eCommons, School of Environmental Sustainability: Faculty Publications and Other Works, http://dx.doi.org/10.1007/ s00244-014-0029-3

This Article is brought to you for free and open access by the Faculty Publications and Other Works by Department at Loyola eCommons. It has been accepted for inclusion in School of Environmental Sustainability: Faculty Publications and Other Works by an authorized administrator of Loyola eCommons. For more information, please contactecommons@luc.edu. c) (†) $\Theta$

This work is licensed under a Creative Commons Attribution-Noncommercial-No Derivative Works 3.0 License. (C) Springer Science+Business Media New York 2014 
1 Effects of St. Lucie River (FL) saltwater sediments on the amphipod (Ampelisca abdita) and the hard shell clam (Mercenaria mercenaria)

3

4 Tham C. Hoang ${ }^{1,2}$, Gary M. Rand ${ }^{1 *}$

$5 \quad{ }^{1}$ Florida International University, Southeast Environmental Research Center, Earth \& Environment

${ }^{2}$ Present address: Institute of Environmental Sustainability, Loyola University Chicago, Chicago, Illinois, USA

9

*Corresponding author

Dr. Gary M. Rand

Ecotoxicology and Risk Assessment Laboratory 


\section{Abstract}

The St. Lucie estuary ecosystem in South Florida has been noted to be contaminated with metals and pesticides. Our earlier studies showed that aquatic organisms, especially benthic species in

21 the St. Lucie estuarine ecosystem are at high risk of copper $(\mathrm{Cu})$ exposures. The objectives of this

22 study are to conduct tests with separate groups of organisms exposed to 7 field-collected sediment

23 samples from the St. Lucie River according to standard procedures to evaluate toxicity and tissue

24 concentrations of $\mathrm{Cu}$ and zinc ( $\mathrm{Zn})$. Short term and long term whole sediment acute toxicity tests were

25 conducted with Ampelisca abdita and Mercenaria mercenaria. Analysis of sediment chemical

26 characteristics showed that $\mathrm{Cu}$ and $\mathrm{Zn}$ are most concern because their concentrations in $86 \%$ of the

27 sediments were higher than the threshold effect concentrations for Florida sediment quality assessment

28 and the NOAA SQuiRTsnational $\mathrm{Cu}$ sediment quality guidelines. There was no significant effect on

29 survival of the tested organisms. Elevated $\mathrm{Cu}$ and $\mathrm{Zn}$ concentrations in the test organisms were found.

30 Dry weight of the tested organisms was inversely related to $\mathrm{Cu}$ and $\mathrm{Zn}$ concentrations in sediments and

31 organisms. The effects on organism weight and $\mathrm{Cu}$ and $\mathrm{Zn}$ uptake raise a concern about the organism

32 population dynamics of the ecosystem because benthic organisms are primary food sources in the St.

33 Lucie system and are continuously exposed to the $\mathrm{Cu}$ and $\mathrm{Zn}$ contaminated sediments for their life

34 cycle. The present study also indicates that $\mathrm{Cu}$ and $\mathrm{Zn}$ exposures via sediment ingestion were more 35 important than pore water exposure.

36

37 Key words: $\mathrm{Cu}$ uptake, $\mathrm{Cu}$-contaminated sediment, St. Lucie River sediments, Ampelisca abdita, 38

Mercenaria mercenaria 


\section{Introduction}

The St. Lucie Estuary (SLE) watershed is composed of five major drainage basins and several smaller basins in the northern portion of St. Lucie County, Florida. It contains the most concentrated

42 citrus agriculture acreage in South Florida. The SLE is located on the Martin/St. Lucie County line. The inner SLE is comprised of the North Fork and the South Fork of the St. Lucie River (SLR) and has a

44 total surface area of 6.4 square miles. The two forks converge to form a single middle estuary with a surface area of 4.7 square miles. The middle estuary extends east from approximately 5 miles until it meets the Indian River Lagoon, which opens to the Atlantic Ocean at the St. Lucie Inlet. A heavier

47 concentration of citrus agriculture $(\sim 60 \%)$ land use potentially affects the drainage basins into the North Fork compared to the South Fork ( $45 \%)$ of the SLR. In 1972, the Florida Trustees recognized the ecological importance of the North Fork of the St. Lucie River by designating it an Aquatic Preserve/Outstanding Florida Water.

Copper has a long history of use in agriculture (e.g., citrus groves) as a fungicide and fertilizer in south Florida (Alva et al. 1995). In the early 1900’s copper containing fertilizers for citrus groves accounted for as much as $34 \mathrm{~kg} \mathrm{Cu} / \mathrm{ha}$ annually and fungicidal sprays contributed an additional 10kg

$54 \mathrm{Cu} / \mathrm{ha}$ annually. Surface soils $(0-15 \mathrm{~cm})$ for mature citrus groves contained as much as $540 \mathrm{~kg} \mathrm{Cu} / \mathrm{ha}$.

55 Increased levels of copper in South Florida soils have been a result of repeated applications of copper 56 over several decades to agricultural areas and soil copper concentrations increase proportional age of 57 citrus production (Reuther and Smith, 1952). According to the U.S. Department of Agriculture in 2005, over 500,000 kg of copper (as copper hydroxide, copper sulfate or basic copper) were applied to grapefruit, orange, tangelo, tangerine and temple crops on 259,563 ha in Florida (USDA 2006). These quantities do not reflect use of $\mathrm{Cu}$ on other citrus crops or the use of copper sulfate and chelated $\mathrm{Cu}$

61 formulations (e.g., Cutrine-Plus, Komeen, etc.) as algaecides-herbicides, which are permitted by the 
62 Florida Department of Environmental Protection (FDEP) for control of nuisance planktonic and

63 filamentous algal and vascular plants (Leslie, 1990). Note that $\mathrm{Cu}$ also does leach from boats into both

64 fresh- and salt-water (e.g., harbors and marinas) because it is a component of antifouling pants. More

65 recently, statewide pesticide usage data (based on total lbs a.i. applied) compiled by the Florida

67 active ingredients (a.i.) ranked copper hydroxide (1,176,500 lbs. a.i. applied) number 5 out of 10 pesticides and the most applied fungicide (number 1 out of 10 fungicides).

A comparison of aqueous $\mathrm{Cu}$ concentrations in agriculture and non-agriculture watersheds shows

70 higher concentrations in runoff where agriculture was practiced compared to runoff near non-agriculture

71 land (Dietrich et al., 2001). Copper loads in surface runoff are related to total Cu in soils, soil

72 properties, metal characteristics and environmental factors, especially in sandy soils (He et al., 2006).

73 Enrichment of $\mathrm{Cu}$ in runoff will adversely affect receiving surface water quality (Moore et al., 1998).

74 As a result of the use of copper in agriculture in St. Lucie County, it appears that concentrations of 75 copper (and other contaminants, such as $\mathrm{Zn}$ ) from drift and/or from surface runoff of contaminated soils 76 (or soil erosion) may also produce exposures that adversely affect saltwater benthic communities, when 77 the $\mathrm{Cu}$-contaminated soils reach and become incorporated as part of the sediments of the St. Lucie River (Haunert 1988, Trefry and Trocine 2011, Trocine and Trefry 1993, 1996). system. Sediment chemistry data indicate that Florida coastal sediments in several areas are contaminated with metals (Long and Morgan 1990, Delfino et al. 1991, FDEP 1994), especially Cu

Our early laboratory results indicate that copper-contaminated Florida agricultural soils that are

82 flooded likely promote the release of $\mathrm{Cu}$ from soils producing adverse effects on freshwater organisms 83 (Hoang et al. 2008a, 2009a, b). In addition, we showed high potential ecological risks to aquatic species 84 as a result of $\mathrm{Cu}$ exposures in sediment and water and high probability of exceedences of the Florida 
Department of Environmental Protection Sediment Quality Assessment Guideline values for the Threshold Effect Concentration and the Probable Effect Concentration (FDEP SQAGs TECs and PECs) for $\mathrm{Cu}$ (FDEP 2003) in the St. Lucie River (Schuler et al. 2008). More recently, Carriger and Rand 2013 (in press) also showed high ecological risks of $\mathrm{Cu}$ in this system to aquatic organisms. The objectives of the present study are to conduct whole sediment toxicity studies with the clam (Mercenaria mercenaria) and the benthic amphipod (Ampelisca abdita) exposed to field-collected sediment samples from the St. Lucie River to evaluate uptake (bioconcentration) and toxicity of $\mathrm{Cu}$ and $\mathrm{Zn}$.

\section{Materials and Methods}

Sediments used in the present study ( $n=7 ; 6$ test and 1 reference site) were collected by the National Oceanic and Atmospheric Administration (NOAA) from the St. Lucie River, south Florida, USA and transferred to the Ecotoxicology and Risk Assessment Laboratory (ERAL) of Florida International University on April 5-7, 2011 for toxicity testing (Figure 1). ERAL is a NELACaccredited laboratory facility for fresh- and salt-water toxicity testing. Sediment samples were labeled NOA2581 (reference site in the South Fork of the SLE) along with six test sites as NOA2569, NOA2334, NOA2640, NOA2639, NOA 2333, and NOA2570 (sites in the North Fork of the SLE). Prior to aquatic testing, sediments were physically characterized and background concentrations of metals and organic pollutants were analyzed. The sediments were also analyzed for acid volatile sulfide (AVS) and simultaneously extracted metals (SEM). Using the AVS/SEM ratio, we can predict the bioavailability of metals (Berry et al. 1996).

Two separate types of studies were conducted with the 7 field-collected sediment samples to evaluate mortality, growth and accumulation; one study with the tube-dwelling amphipod (A. abdita), which is a common standard saltwater benthic test species used for whole-sediment toxicity and 
bioaccumulation tests and one study with the hard shell clam (M. mercenaria) which is a native species in the St. Lucie system. Exposures to the field-collected sediments in both studies were in a flowthrough water system to ensure consistent water quality conditions (e.g., low ammonia concentrations). Flow-through systems were calibrated prior to testing to ensure correct water placements in test chambers over each 24-hour time period. Saltwater for the flow-through system was obtained from a saltwater well (with Biscayne Bay water) which was air-sparged, carbon-filtered and UV-sterilized with a salinity of $31 \mathrm{ppt}$ and a $\mathrm{pH}$ of $8.0-8.5$.

Toxicity tests with A. abdita were 10 days in duration and were conducted according to the methods for measuring the toxicity and bioaccumulation of sediment-associated contaminants with marine invertebrates (U.S. EPA. 1994). A. abdita were obtained from a commercial supplier. An initial subsample of the A. abdita population was used for length and weight measurements and tissue analyses $(\mathrm{Cu}, \mathrm{Zn})$ for background data. There were 10 organisms per replicate with 8 replicates per sediment sample site. Organisms (10) were randomly distributed in each test chamber with $350 \mathrm{ml}$ of water and $150 \mathrm{ml}$ of sediment ( 8 test chambers /site; 80 organisms exposed/site) in the water bath of the flowthrough water system ( 2 test chamber water volume turnovers/24h). Water quality monitoring for the tests included salinity, ammonia and $\mathrm{pH}$ measurements at test initiation and at test termination. Temperature and dissolved oxygen were measured daily. Salinity, ammonia, and $\mathrm{pH}$ were measured using a YSI conductivity/salinity meter (YS Inc, Yellow Springs, Ohio, USA), an Accumet ${ }^{\circledR}$ Ammonia Electrode (Fisher Scientific, Pittsburgh, PA, USA), and an Accumet pH meter (Vernon Hills, Illinois, USA), respectively. Water temperature and dissolved oxygen concentrations were measured using a YSI dissolved oxygen meter (YS Inc., Yellow Springs, Ohio, USA). Mortality of A. abdita was measured at test termination along with growth (dry weight and length) of surviving organisms. The quality criterion for control survival was $80 \%$. Tissue concentrations (whole body) of $\mathrm{Cu}$ and $\mathrm{Zn}$ were measured at test 
131 initiation and again at test termination. To increase the detection limits for $\mathrm{Cu}$ and $\mathrm{Zn}$, surviving

132 organisms from all replicates were combined for each treatment and digested with $\mathrm{HNO}_{3}$ acid using a

133 Hotblock and based on the U.S. EPA Method 3050B (U.S. EPA 1996a) for tissue Cu and Zn analyses.

134 Analysis of $\mathrm{Cu}, \mathrm{Zn}$, and other minerals were conducted with an inductively coupled plasma

135 spectrometer (Thermo Scientific Inc. 5225 Verona Road, Madison, WI 53711).

136 In addition, a 28-day bioconcentration study was conducted similarly to U.S. EPA Ecological

137 Effects Test Guidelines (U.S. EPA, 1996b) except that sediment was the source of the contaminants (not

138 water exposure). The hard shell clam (M. mercenaria), an economically important native species in the

139 SLR system was the test species and only a 28-day uptake phase (without a depuration phase) was used.

140 M. mercenaria juveniles were obtained from a commercial supplier. An initial subsample of the $M$.

141 mercenaria juvenile population was used for weight measurements and tissue analyses of $\mathrm{Cu}$ and zinc.

142 There were 50 organisms per replicate with 2 replicates per sediment sample site used. Organisms (50)

143 were randomly distributed to an $18 \mathrm{~L}$ test chamber with $12 \mathrm{~L}$ of water and $3-4 \mathrm{~cm}$ of sediment $(2$ test

144 chambers /site; 100 organisms exposed/site) in a flow-through water system (4 tank water volume

145 turnovers/24h). Water quality monitoring for the test included salinity, conductivity, and $\mathrm{pH}$

146 measurements for the first 3 days, daily and again at the end of the test. Temperature and dissolved

147 oxygen were measured daily. Mortality was measured on days 3, 7, 14, 21 and 28. Tissue samples $(n=4)$

148 were also collected and measured on days 3, 7, 14, 21 and 28 of surviving organisms for $\mathrm{Cu}$ and $\mathrm{Zn}$.

149 The quality criterion for control survival was $80 \%$. Overlying and porewater samples were also

150 collected when the tissue samples were collected for analyses of $\mathrm{Cu}, \mathrm{Zn}$ and dissolved organic carbon

151 (DOC). Porewater was collected by centrifuging the sediments at $2500 \mathrm{~g}$ and $4^{\circ}$ for 30 minutes (Ankley

152 et al. 1991). The samples were filtered with $0.45 \mu \mathrm{m}$ filters prior to analysis. DOC was analyzed with a

153 Shimadzu TOC-5000 (Shimadzu Scientific Instruments, Columbia, MD, USA). Measurement of water 
154 quality and tissue $\mathrm{Cu}$ and $\mathrm{Zn}$ concentrations were conducted as described for the A. abdita test above.

155 Digestion of sediment, clam, and amphipod samples for analysis of $\mathrm{Cu}$ and $\mathrm{Zn}$ were conducted at 156 Loyola University Chicago.

157 At the end of the study, survival, dry weights, $\mathrm{Cu}$ and $\mathrm{Zn}$ tissue concentrations were analyzed to 158 determine whether there were statistically significant $(p<0.05)$ treatment-related effects (responses) of 159 the test substance. The ANOVA F-test was used to test the null hypothesis; that the effects of all 160 sediments including the reference sediment are the same. Tissue $\mathrm{Cu}$ and $\mathrm{Zn}$ concentrations at the end of 161 the tests or at time intervals during the test (M. mercenaria test only) were compared with initial $\mathrm{Cu}$ and 162 Zn concentrations (background) using Dunnett's procedure. Multiple correlations between dry weight, 163 tissue $\mathrm{Cu}$ and $\mathrm{Zn}$ concentrations, sediment $\mathrm{Cu}$ and $\mathrm{Zn}$ concentrations were conducted to determine 164 cause-effects (response) relationship. All statistical analysis was conducted using SAS (version 9.2).

\section{Results and discussion}

167

\section{Sediment characteristics and chemistry}

Characteristics of the sediments are shown in Table 1. In general, the cation exchange capacity was high which suggests that the sediments have high potential to retain metals. Results of AVS and total SEM are shown in Table 1. AVS for sediments NOA2333, NOA2334, NOA2569 and NOA2570 were below the detection limits. The total SEM/AVS ratios for these sediments were estimated based on the detection limits of AVS for those samples. The ratio of total SEM/AVS for all sediments was greater than 1 which suggests that metals in the sediments are more bioavailable to benthic organisms (Ankley et al.1996, McGrath et al. 2002).

Concentrations of metals and minerals in the sediments from the sites are shown in Table $2 \mathrm{a}$. Concentrations of the metals and minerals varied from site to site. Among the toxic metals, $\mathrm{Cu}$ and $\mathrm{Zn}$ 
177 were of most concern because concentrations of both metals exceeded (with $\mathrm{Cu} 6$ out of 7 sediments;

178 with $\mathrm{Zn} 5$ out of 7 sediments) the sediment quality assessment guideline (SQAGs) threshold effect

179 levels (TELs) for coastal and marine waters set by the Florida Department of Environmental Protection 180 (FDEP) for $\mathrm{Cu}(18.7 \mathrm{mg} / \mathrm{kg})$ and $\mathrm{Zn}(124 \mathrm{mg} / \mathrm{kg}$, dw) (MacDonald et al.1996). Cu concentrations of the 1816 sediments also exceeded the informal quick screening marine sediment value (effect range low (ERL) 182 concentration $=34 \mathrm{mg} / \mathrm{kg}$ ) used for the NOAA SQuiRTs (Buchman, 1999; Long et al. 1995). Zn 183 concentrations were equal to or greater than the ERL $(150 \mathrm{mg} / \mathrm{kg})$ for 3 sediments. Neither copper nor 184 zinc concentrations exceeded the NOAA SQuiRTs ERM (effects range median) values which are 185 representative of concentrations above which effects frequently occur $(\mathrm{Cu} \mathrm{ERM}=270 \mathrm{mg} / \mathrm{kg} ; \mathrm{Zn} \mathrm{ERM}$ $186=410 \mathrm{mg} / \mathrm{kg}$ ). Concentrations of the other toxic metals (e.g., As, $\mathrm{Cd}, \mathrm{Cr}, \mathrm{Ni}, \mathrm{Pb}$ ) in the sediments were 187 not detected or were less than the FDEP TEC SQAGs and the NOAA SQuiRTs ERLs. In a sediment 188 survey in 1982 from the St. Lucie Estuary (SLE) the mean concentration of Cu and Zn were 41 189 (maximum: $229 \mathrm{mg} / \mathrm{kg}$ ) and 67 (maximum: $235 \mathrm{mg} / \mathrm{kg}$ ) mg/kg, respectively (Haunert, 1988). Metal 190 concentrations were related to particle size and organic content; as the quantity of clay- and silt-sized 191 particles increased the concentrations of these metals increased. The sediment in the central part of the 192 North Fork of the SLE had the highest concentrations of organic material with the highest 193 concentrations of metals. In 1992, a sediment survey in the Indian River Lagoon, system also showed 194 high concentrations of $\mathrm{Cu}$ above background in sediments and clams (Trocine and Trefry, 1993, 1996). 195 In a follow-up sediment survey in 2006-2007, the mean concentrations of $\mathrm{Cu}$ (44mg/kg; maximum: 162 $196 \mathrm{mg} / \mathrm{kg}$ ) and Zn (95 mg/kg; maximum: $231 \mathrm{mg} / \mathrm{kg}$ ) increased from the 1992 survey (Trefry and Trocine, 197 2011). 
from the sites except for DDT metabolites (e.g., p,p-DDD) (Table 2b). The total concentrations of DDTs in 3 out of the 7 sediments were higher than the NOAA SQuiRTs ERL concentration $(1.58 \mathrm{mg} / \mathrm{kg}, \mathrm{dw})$.

At the end of the M. mercenaria bioconcentration study, sediments samples were collected for

$202 \mathrm{Cu}$ and $\mathrm{Zn}$ analysis. In general, $\mathrm{Zn}$ and $\mathrm{Cu}$ concentrations at the beginning (day 0) and the end (day 28)

203 of the study were not significantly different except for NOA 2581 and 2639, Cu and $\mathrm{Zn}$ concentrations

204 at the end of the study appeared to be higher than those at the beginning (Table 3). This result indicates

205 that $\mathrm{Cu}$ and $\mathrm{Zn}$ did not desorb to the overlying water. The high percent of silt, clay, and organic matter

206 in the sediments explains why little $\mathrm{Cu}$ and $\mathrm{Zn}$ release occur during the study. $\mathrm{Zn}$ and $\mathrm{Cu}$ concentrations

207 in the sediments were also significantly correlated, revealing that $\mathrm{Zn}$ and $\mathrm{Cu}$ would come from the same

208 source.

\section{Water quality and chemistry}

Water quality conditions for both studies were within U.S. EPA test guideline requirements. For

212 the A. abdita test, the 10-d average temperature, $\mathrm{DO}, \mathrm{pH}$, and salinity of the overlying water during the

213 test were $21 \pm 1^{\circ} \mathrm{C}, 7.1 \pm 1.2 \mathrm{mg} / \mathrm{L}, 8.26 \pm 0.07$, and $30 \pm 1 \mathrm{ppt}$, respectively. Ammonia concentration

214 ranged from 0.4 to $1 \mathrm{mg} / \mathrm{L}$ which were less than the U.S. EPA criteria at a pH of $8.26(3.4 \mathrm{mg} / \mathrm{L})$.

215 Concentrations of dissolved $\mathrm{Cu}$ in the overlying and pore water were at the background level $(6 \mu \mathrm{g} / \mathrm{L} \mathrm{Cu}$

216 in saltwater used for testing). Concentration of dissolved $\mathrm{Zn}$ in the overlying and pore waters ranged

217 from the background level $(6 \mu \mathrm{g} / \mathrm{L} \mathrm{Zn})$ to $33 \mu \mathrm{g} / \mathrm{L} \mathrm{Zn}$. These results may be explained by the high

218 percent of silt, clay, and organic matter in the sediments, resulting in negligible desorption of $\mathrm{Cu}$ and $\mathrm{Zn}$

219 from the sediments to water. These results also suggest low bioavailability of $\mathrm{Cu}$ and $\mathrm{Zn}$ in pore water.

220 Concentrations of dissolved organic matter in the overlying water were low (<5mg/L). For the $M$. 
221 mercenaria study, the 28 - $\mathrm{d}$ average temperature, $\mathrm{DO}, \mathrm{pH}$, and salinity of the overlying water were $24 \pm$

$2220.1^{\circ} \mathrm{C}, 6.6 \pm 0.2 \mathrm{mg} / \mathrm{L}, 8.24 \pm 0.11$, and $30 \pm 1 \mathrm{ppt}$, respectively. Similar to the $A$. abdita study,

223 concentrations of dissolved $\mathrm{Cu}$ and $\mathrm{Zn}$ in the overlying and pore water were at the background levels,

224 suggesting low $\mathrm{Cu}$ and $\mathrm{Zn}$ bioavailability. Concentrations of DOM in the overlying water were also low $225(<4 \mathrm{mg} / \mathrm{L})$.

226

227

228

229

230

\section{Effects on survival, $\mathrm{Cu}$ and $\mathrm{Zn}$ uptake, and growth}

Since concentrations of $\mathrm{Cu}$ and $\mathrm{Zn}$ exceeded both the Florida sediment quality guidelines and the NOAA SQuiRTs and the other toxic metals (e.g., As, $\mathrm{Cd}, \mathrm{Cr}, \mathrm{Ni}, \mathrm{Pb}$ ) were below these numerical values, the discussion in this section considers only $\mathrm{Cu}$ and $\mathrm{Zn}$. Results of organism survival are shown in Table 4. Mortality of A. abdita and M. mercenaria ranged from 14\% (NOA2333) to 28\% (NOA2581) and 0\% (NOA2639, NOA2570) to 4\% (NOA2569), respectively. In general, there was no significant difference between mortality of the tested organisms for the field-collected reference and contaminated sediments. Although the results of SEM and AVS indicate metal bioavailability, the high organic matter content in the sediments most likely decreased $\mathrm{Cu}$ and $\mathrm{Zn}$ bioavailability and toxicity. No mortality was reported in a similar study conducted by Rule (1985) with M. mercenaria and sediments collected from $\mathrm{Cu}(3 \mu \mathrm{mol} / \mathrm{g})$ compared to the present study. 
244 and $\mathrm{Cu}$ from the sediments. As discussed above, results of the sediment chemistry (e.g., total SEM/AVS

$245>1$ ) indicate metal bioavailability. This might explain the $\mathrm{Cu}$ and $\mathrm{Zn}$ accumulation in M. mercenaria.

246 Rule (1985) also found that M. mercenaria accumulated $\mathrm{Zn}$ from the sediments which had a similar $\mathrm{Zn}$

247 sediment concentration to the present study. However, Zn accumulation by M. mercenaria in the Rule

248 (1985) study was approximately half the Zn accumulation in the present study but Zn bioavailability in

249 the present study was higher than in the Rule (1985) study.

250

$\mathrm{Cu}$ and $\mathrm{Zn}$ concentrations in $M$. mercenaria tissue in the present study did not increase over time.

251 This is in contrast with our earlier studies with freshwater Florida apple snails (Pomacea paludosa)

252 where apple snails accumulated $\mathrm{Cu}$ from sediment overtime (Hoang et al. 2008b, Hoang et al. 2011). Cu

253 and $\mathrm{Zn}$ concentrations in M. mercenaria shell were also below the detection limits but in general,

254 negligible $\mathrm{Cu}$ and $\mathrm{Zn}$ concentrations were detected in apple snail shells as well (Hoang et al. 2008b).

255

$\mathrm{Zn}$ and $\mathrm{Cu}$ concentrations in $A$. abdita varied from site to site and ranged from 111 (NOA2569) to

$256355 \mathrm{mg} / \mathrm{kg} \mathrm{dw}$ (NOA2581) and 65 (background) to $364 \mathrm{mg} / \mathrm{kg} \mathrm{dw}$ (NOA2570), respectively (Table 6).

257 In general, $\mathrm{Cu}$ concentrations in A. abdita were higher at the end of the study than at the beginning of

258 the study for all sites. There was a positive correlation between the A. abdita tissue Cu concentration

259 and sediment $\mathrm{Cu}$ concentration (Table 10). Results of the present study indicate that A. abdita

260 accumulated $\mathrm{Cu}$ from the sediments during the 10 day study. Results of the sediment chemistry suggest

$261 \mathrm{Cu}$ bioavailability and therefore explain the $\mathrm{Cu}$ accumulation in $A$. abdita. The final tissue results

262 obtained for $A$. abdita in the present study were similar to the tissue $\mathrm{Cu}$ concentrations found in our

263 earlier 10 day study with the freshwater benthic amphipod, Hyalella azteca exposed to Cu-contaminated

264 soils from citrus agricultural sites near the St. Lucie watershed (Hoang et al. 2009b). Hoang et al. 2009b

265 showed that $\mathrm{Cu}$ tissue (whole body) concentrations ranged from 128 to $294 \mathrm{mg} / \mathrm{kg}$ after 10 days

266 exposure when initial $\mathrm{Cu}$ soil concentrations ranged from 5-234 mg/kg from these citrus agricultural 
sites. Note that in this $\mathrm{A}$. abdita study, $\mathrm{Cu}$ tissue concentrations were up to 6 times the initial $\mathrm{Cu}$ tissue concentrations following only 10 days of exposure and similar to the response of the freshwater amphipod, H. azteca following 10 day exposures. Furthermore, the tissue results for both freshwater and saltwater benthic species, following exposures to $\mathrm{Cu}$ in sediment, raise some interesting issues for burrowing and tube dwelling in faunal benthic species which have habitats in close contact with sediment (pore water) for part or most of their life cycle. The influence on $\mathrm{Cu}$ uptake in these benthic species on upper trophic level diets and species has not been extensively investigated.

Also note that accumulated metal within and between invertebrate taxa, vary considerably, even in the absence of anthropogenic pollution (Rainbow, 2002). For trace metals like zinc and copper, which play essential roles in metabolism of most invertebrate, the quantity necessary to perform these functions may also vary widely within and between invertebrate taxa. For aquatic organisms used in toxicity tests, it is also critical to know the background holding, culture and water quality conditions because if test organisms are obtained from different aquaculture sources the trace metal concentrations in their tissues and organs may be different and will obviously reflect prior water quality and diet they were exposed to. Background tissue concentrations (day 0) of zinc (Table 6) for A. abdita were as high as concentrations at the end of the $10 \mathrm{~d}$ treatment and therefore precluded any comparisons of zinc tissue concentrations. In addition, to being cautious when obtaining organisms from aquaculture sources for aquatic toxicity testing, the use of field-collected species requires even greater awareness for use in toxicity testing especially for the evaluation of hazards and risks.

The dry weight of M. mercenaria and A. abdita are shown in Tables 7 and 8, respectively. Dry weight of M. mercenaria shell, tissue, and whole body from days 0-28 ranged from 194 to 355 $\mathrm{mg} /$ organism, 5 to $8 \mathrm{mg} /$ organism, and 198 to $552 \mathrm{mg} /$ organism, respectively. In general, dry weight was not affected by sediment exposure up to day 21 . However, there was a slight negative correlation 
290

291

292

293

294

295

296

297

298

299

300

301

302

303

304

305

306

307

308

309

310

311

312

between $M$. mercenaria tissue weight and $\mathrm{Cu}$ and $\mathrm{Zn}$ concentrations in the sediments at the end of the study (day 28) (Table 9). This suggests that $\mathrm{Cu}$ and $\mathrm{Zn}$ concentrations in the sediments may have started to produce an effect on M. mercenaria growth (as measured by dry weight) after 28 days exposure and that in the experimental design the uptake (exposure) phase was too short and it should have been extended. Clams that live in these sediments will be continuously exposed to $\mathrm{Cu}$ and $\mathrm{Zn}$ for most of their life cycle in the in the St. Lucie system, with little time for depuration and recovery, hence the effect might be greater. Results of the present study thus raise concern about the population dynamics of bivalves in the St. Lucie ecosystem.

The St. Lucie estuarine ecosystem has been documented as a $\mathrm{Cu}$-contaminated system for decades (Long and Morgan 1990, Delfino et al. 1991, FDEP 1994). The cause of Cu contamination is likely due to $\mathrm{Cu}$ release from the sandy soils of nearby citrus agriculture farms through surface runoff. $\mathrm{Cu}$ will continuously be used in citrus agriculture, with a long season of application thus increasing the $\mathrm{Cu}$ load and release from soils into runoff water, adding more $\mathrm{Cu}$ into the St. Lucie estuary and the Everglades ecosystems (Hoang et al. 2008a, Hoang et al. 2009a). This is also based on an exposure analyses of copper concentrations in water and sediment in south Florida aquatic systems for over 15 years from 1990-2008, which shows high $\mathrm{Cu}$ concentrations in aquatic systems and potential risks to mollusks in the North and South forks of the SLR and in the SLE (Carriger and Rand, in press).

Dry weight of $A$. abdita was negatively correlated with tissue $\mathrm{Cu}$ concentration (Table 10). This suggests that tissue $\mathrm{Cu}$ concentrations affected $A$. abdita's growth. Since water concentrations of $\mathrm{Cu}$ and $\mathrm{Zn}$ were at typical background levels, the effects of $\mathrm{Cu}$ and $\mathrm{Zn}$ on $M$. mercenaria tissue weight and A. abdita weight would be due to exposure via sediment ingestion. Furthermore, tissue $\mathrm{Cu}$ and $\mathrm{Zn}$ concentrations were correlated with both sediment $\mathrm{Cu}$ and $\mathrm{Zn}$ concentrations, suggesting that $\mathrm{Cu}$ and $\mathrm{Zn}$ simultaneously entered the organisms. Ingestion of $\mathrm{Cu}$ - and $\mathrm{Zn}$-bound to organic matter in sediments 
313 was thus a major exposure route. Several studies have demonstrated that metal exposure to clams and 314 amphipods via food and sediment ingestion was more important than pore water exposure (Eriksson and 315 Sundelin 2002, Labreche et al. 2002, Forbes et al. 1998).

317 Summary and conclusions

The present study showed that sediments collected from the St. Lucie estuarine system contained

$319 \mathrm{Cu}$ and $\mathrm{Zn}$ concentrations that exceeded both the Florida State sediment quality criteria and NOAA

320 SQuiRTs sediment values. The total concentration of DDTs in 3 out of the 7 sediments was also higher

321 than the NOAA SQuiRTs sediment values. M. mercenaria and A. abdita exposed to the St. Lucie

322 sediments resulted in $\mathrm{Cu}$ accumulation in $\mathrm{A}$. abdita and $\mathrm{Cu}$ and $\mathrm{Zn}$ accumulation in $M$. mercenaria. The

323 present study also indicated that $\mathrm{Cu}$ and $\mathrm{Zn}$ exposures via sediment ingestion were most likely an

324 important route of exposure. However, there was no effect of the contaminated sediments on organism

325 survival.

Elevated $\mathrm{Cu}$ and $\mathrm{Zn}$ concentrations in the tissues and the effects on the weight of both $M$.

327 mercenaria and $A$. abdita raise concerns for the long-term viability of invertebrate populations, for

328 higher trophic organisms in the St. Lucie estuarine ecosystem and the population dynamics of the 329 ecosystem because these are only two organisms that are primary food resources in the St. Lucie system 330 which are exposed to the contaminated sediments for either part or their entire life cycles. The 331 significance of these results can only be fully realized when studies are conducted with other organisms 332 exposed to a greater number field-collected sediments from a larger number of sediment sites. These 333 studies gain in importance in lieu of the continued input of these metals into the environment. 


\section{Acknowledgement}

We would like to thank Dr. Joan Browder-National Oceanic and Atmospheric Administration (Miami, FL) for funding this research under contract WC133F-09-CQ-0006-“Ecological Studies of Trophic Web Species and Potential Harmful Materials found in the St. Lucie Estuarine System” with Florida International University. We are grateful to Indra Chacin Lares, Abraham Smith and Brandi Echols in the Ecotoxicology and Risk Assessment Laboratory of Florida International University for their assistance with conducting the study. This publication is SERC contribution \# and ISE contribution \#.

\section{References}

Alva, A.K., Graham, J.H., Anderson, C.A. 1995. Soil-pH and copper effects on young Hamlin Orange Trees. Soil Science Society of America Journal 59: 481-487

Ankley, G.T. 1991. Predicting the toxicity of bulk sediments to aquatic organisms with aqueous test fractions: Pore water vs. Elutriate. Environ. Toxtcol. Chem. 10:1359-1366

Ankley, G.T., Di Toro, D.M., Hansen, D.J., Berry, W.J., 1996. Technical basis and proposal for deriving sediment quality criteria for metals. Environ. Toxtcol. Chem. 15: 2056-2066.

Berry, W.J., Hansen, D.J., Mahony J.D., Robson, D.L., DiToro, D.M., Shipley B.P., Rogers, B.P., Corbin J.M., Boothman,W.S. 1996. Predicting the toxicity of metal-spiked laboratory sediments using acid-volatile sulfide and interstitial water normalizations. Environ. Toxtcol. Chem. 15:20672079.

Buchman, M.F. 1999. NOAA screening quick reference tables, NOAA HAZMAT report 99-1, Seattle WA, coastal protection and restoration division, National Oceanic and Atmospheric Administration, 12 pages. 
Carriger, J.F., Rand, G.M. Copper in saltwater ecosystems of South Florida: Use of probabilistic aquatic risk assessment methodology and application of kriging methods to determine potential systems at risk. In press.

Delfino, J.J., Coates, LA., Davis, W.M., Garcia, K.L., Jacobs, M.W., Marincic, K.J., Signorella, L.L. 1991. Toxic Pollutants in Discharges, Ambient Waters, and Bottom Sediments, Volume I and 11, submitted to Florida Department of Environmental Regulation, Tallahassee, FL. University of Florida; Gainsville, FL.

Dietrich, A.M., Gallagher, D.L., Klawiter, K.A. 2001. Inputs of copper-based crop protectants to coastal creeks from pasticulture runoff. J Amer Wat Resour Assoc 37: 281-293.

Eriksson Wiklund, A., Sundelin, B. 2002. Bioavailability of metals to the ampiphod Monoporeia affinis: interactions with authigenic sulfides in urban brackish-water and freshwater sediments. Environ. Toxicol. Chem. 21: 1219-1228.

Florida Department of Agriculture and Consumer Services (FDACS). 2010. Summary of Agricultural Pesticide Use in Florida: 2007-2009, October 2010. Accessed May 25, 2011. http://www.flaes.org/pdf/PUI_narrative_2010.pdf.

Florida Department of Environmental Protection (FDEP).1994. Florida Coastal Sediment Contaminants Atlas, Tallahassee, FL: Office of the Secretary. 112 pp.

Florida Department of Environmental Protection (FDEP). 2003. Development and evaluation of numerical sediment quality assessment guidelines for Florida inland waters. Report by MacDonald, Environmental Sciences Ltd. Technical Report.

Forbes, T.L., Forbes, V.E., Giessing, A., Hansen, R., Kure. L.K. 1998. Relative role of pore water versus ingested sediment in Bioavailability of organic contaminants in marine sediments. Environ. Toxicol. Chem.17:2453-2462. 
Haunert, D.E. 1988. Sediment characteristics and toxic substances in the St. Lucie estuary, Florida. Technical publication 88-10. Environmental sciences Division, resource Planning Department, South Florida Water Management District. 42pp.

He, Z.L., Zhang, M., Yang, X.E., Stoffella, P.J., 2006. Release behavior of copper and zinc from sandy soils. Soil Science Society of America Journal 70, 1699-1707.

Hoang, T. C., Rogevich, E. C., Rand, G. M., Gardinali, P. R., Frakes, R. A., \& Bargar, T. A. 2008 a. Copper desorption in flooded agricultural soils and toxicity to the Florida apple snail (Pomacea paludosa): implications in Everglades restoration. Environ. Pollut, 154: 338-347.

Hoang, T. C., Rogevich, E. C., Rand, G. M., Frakes, R. A. 2008b. Copper uptake and depuration by juvenile and adult Florida apple snails (Pomacea paludosa). Ecotoxicology, 17:605-615.

Hoang, T.C., Schuler, L.J., Rogevich, E.C., Bachman, P.M., Rand, G.M., Frakes, R.A. 2009a. Copper Release, Speciation, and Toxicity Following Multiple Floodings of Copper Enriched Agriculture Soils: Implications in Everglades Restoration. Wat. Air. Soil Pollut.199, 79-93.

Hoang, T.C., Schuler, L.J., Rand, G.M. 2009b. Effects of Copper in Flooded Florida Agricultural Soils on Hyalella azteca. Arch. Environ. Contam. Toxicol. 56: 459-467.

Hoang, T.C., Pryor, R.L., Rand, G.M., Frakes, R.A. 2011. Bioaccumulation and toxicity of copper in outdoor freshwater microcosms. Ecotoxicol. Environ. Saf. 74: 1011-1020.

Labrech, T.M.C., Dietrich, A.M., Gallagher D.L., Shepherd, N. 2002. Copper toxicity to larval Mercenaria mercenaria (hard clam). Environ. Toxicol. Chem. 21:760-761.

Leslie, A.J., 1990. Aquatic Use of Copper-based Herbicides in Florida. Bureau of Aquatic Plant Management, Florida Department of Natural Resources, Tallahassee, FL. 1e14. 
Long, E.R., Morgan, L.G. 1990. The Potential for Biological Effects of Sediment-sorbed Contaminants Tested in the National Status and Trends Program, Seattle, WA: National Oceanic and Atmospheric Administration.

Long, E. R., MacDonald, D.D., Smith, S.L., Calder, F.D. 1995. Incidence of adverse biological effects within ranges of chemical concentrations in marine and estuarine sediments. Environ. Manag. 19: 81-97.

MacDonald, D.D., Carr R.S., Calder, F.D., Long, E.R., Ingersoll, C.G.1996. Development and evaluation of sediment quality guidelines for Florida coastal waters. Ecotoxicology 5:253-278.

McGrath, J.A., Paquin, P.R., Di Toro, D.M. 2002. Use of the SEM and AVS approach in predicting metal toxicity in sediments. HydroQual, Inc., Mahwah, NJ (USA). Published by the International Council on Mining and Metals, ICMM.

Moore, P.A., Jr., T.C. Daniel, T.C., Gilmour, J.T., Shreve, B.R., Edwards, D.R., Wood, B.H. 1998. Decreasing metal runoff from poultry litter with aluminum sulfate. J. Environ. Qual. 27:92-99.

Rainbow, P.S. 2002. Trace metal concentrations in aquatic invertebrates: why and so what? Environ. Pollut. 497-507.

Reuther, W., Smith P.F. 1952. Iron chlorosis in Florida citrus soils in relation to certain soil constituents. Proc. Fla. State Hortic. Soc. 65: 62-69.

Rule, J,H. 1985. Chemical extractions of heavy metals in sediments as related to metal uptake by grass shrimp (Paleamonetes pugio) and clam (Mercenaria mercenaria). Arch. Environ. Contam. Toxicol. 14: $749-757$.

Schuler, L.J., Hoang, T.C., Rand, G.M. 2008. Aquatic risk assessment of copper in freshwater and saltwater ecosystems of South Florida. Ecotoxicology, 17:642-659 
425 Trefry, J.H., Trocine, R.P. 2011. Metals in sediments and clams from the Indian River Lagoon, Florida:

426 2006-7 versus 1992. Florida Scient. 74: 43-62.

427 Trocine, R.P., Trefry, J.H. 1993. Toxic substances survey for the Indian River Lagoon system. Final

428 report to St Johns River Water Management District. Available from St Johns River Water

429 Management District, Palatka, Fl.

430 Trocine, R.P., Trefry, J.H. 1996. Metal concentrations in sediment, water and clams from the Indian 431 River Lagoon, Florida. Mar. Poll. Bull. 32: 754-759.

432 U.S. Department of Agriculture. 2006. Agricultural chemical usage summary, 2005 fruit summary;

433 National Agricultural Statistical Service, Washington, DC.

434 U.S. Environmental Protection Agency. 1994. Methods for Assessing the Toxicity of Sediment435 associated Contaminants with Estuarine and Marine Amphipods EPA- 600/R-94/025. Office of

436 Research and Development U.S. Environmental Protection Agency, Narragansett, Rhode Island $437 \quad 02882$.

438 U.S. Environmental Protection Agency. 1996a. Acid digestion of sediment, sludges and soils: EPA 439 method 3050B, SW-846 manual, Washington, DC

440 U.S. Environmental Protection Agency. 1996b. Ecological Effects Test Guidelines. Office of 441 Prevention, Pesticides and Toxic Substances, EPA 712-C-96-129, OPPTS 850.1730, Fish BCF. 442 Washington, DC. 